\title{
谈园林的绿化施工与养护管理
}

\author{
王艳春 \\ 盘锦市林业和园林绿化局 \\ DOI:10.18686/bd.v1i11.1087
}

[摘要] 园林绿化工程养护管理工作在园林绿化工程工作中起着举足轻重的作用, 它是一种持续性、长效性的工作, 有较 高的技术要求,园林绿化工程养护管理工作内容包括整体面貌维护、植物保护、绑扎修剪、浇水施肥、花坛花境的花卉种植、 环境保洁、日常管理等内容。园林绿地的建成并不代表园林景观的完成, 只有高质量、高水平的养护管理,园林景观才能逐渐 达到完美的景观效果。

[关键词] 园林绿化;施工;养护

\section{1 园林绿化施工与养护管理的重要性}

随着城市生活水平的提高, 人们的生活节奏也在不断 加快,人们面临着巨大的生存与生活压力。园林绿化工程建 设的最初目的在于改善人们居住环境, 保持生态平衡,但随 着绿化工程逐渐投入使用, 其逐渐扮演着舒缓人们生活压 力, 帮助人们回归自然的作用。目前随着市场化改革深人,绿 化企业之间的竞争越来越激烈, 如何有效提高园林绿化的 施工与氧化管理水平也成为所有绿化企业关注的重点。除 此之外, 园林绿化设计与实施中还需要兼顾地区特色, 这就 需要考虑工程所在地的气候变化与水文条件, 这样可以让 园林绿化工程更具有观赏性。所以实际中完善与提升园林 绿化施工与养护管理技术水平, 促进城市品味的提升, 同时 起到美化城市保护环境的作用。接下来笔者将对园林绿化 工程施工与养护管理进行重点阐述。

\section{2 当前园林绿化施工与养护管理中尚存在的问题}

2.1 生态环境效能方面的问题

在当前园林绿化施工与养护管理中, 最为关键和重要 的问题就是生态环境效能方面的问题, 我们在对这样一个 问题展开说明和分析的时候, 也可以通过以下这个方面来 予以认识: 我们国家在最近几年来城市发展的速度相当之 快,尤其是一些大城市的发展,基本上都是以牺牲环境作为 成本来实现的, 实际上这样一种牺牲和交换代价是非常之 大且难以挽回的,这一点在最近的十年里更为明显和突出。 正是因为这样一种状况, 城市内的绿化生态环境已经遭受 到了巨大的破坏。到目前为止,我们国家各个城市中都进行 了城市的绿化工程, 但是这样一种绿化基本上都还是处于 弥补的阶段, 这与城市本身的绿化还是有着较大程度上的 区别的。

\section{2 在绿化维护成本方面的问题}

绿化维护成本的控制上同样存在着两个方面的问题, 一方面是在现代的城市绿化养护管理中对于外来植物品种 的引入都有一定的盲目性, 但是不同的植物在不同的气候 环境下, 实际的生长和存活状态是有着较大的区别的,因此, 一些不适宜当地环境植物的引进就会使得其在适应和生存
的过程中存在着较大的困难, 具体来说, 就是外来植物抵抗 当地不良环境因子的能力要差很多。除此之外,在维护的过 程当中, 为了保证外来植物能够有和当地植物相当的生长 水平,我们就需要对其倾注较多的特殊照顾,这会使得整体 的绿化与养护成本大大提高。另一方面就主要表现在绿化 植物品种本身的单一性上, 我们在进行绿化设计的过程中 就会发现, 过于单一的植物品种是很难发挥出其咋植物群 落中的效应的, 而合理的植物搭配才能够较好的保障植物 的生长状态, 还能够较好的避免病虫害等不良状况的发生。

2.3 思想层面上的问题

这一点主要是因为现在的城市建设往往更加强调的是 一种政绩上的追求, 这所反映出的也就是某些政务人员的 形式主义思想。在这样一种形式主义思想的控制与要求下, 为了达到某种效果而进行的大面积快速成景, 不仅难以实 现其所希望的效果, 有的时候甚至会使得原生地的植物或 者是生态都遭受到破坏。

\section{3 园林绿化工程施工管理要点}

园林绿化工程施工管理中, 需要重点关注以下几个方 面,促进园林绿化工程施工管理质量。

\section{1 土方回填施工管理}

园林工程基本上都在主要建筑与区域硬件设施建设完 成后才能进行, 这就造成施工中需要面对大量建筑垃圾的 情况。只有将这些建筑垃圾清理干净才能进行后期施工, 同 时土方回填前要对土壤进行详细监测与综合分析, 确保回 填土方是肥沃的土壤, 杜绝出现用建筑垃圾回填的情况, 只 有这样才能确保苗木正常生产, 达成预期设计目的。

3.2 平地整理的管理

植物种植前需要进行场地平整, 将场地中影响植物生 长的石块、玻璃碎渣与建筑垃圾等清理干净,除此之外,施工 方还需要考虑施工所在地的气候情况。植物生长与灌溉的 最近坡度为 2.4-3.6,这种坡度角度还有利于居民的观赏, 提 高工程观赏效果; 最后做好植物周边的防护措施, 尽量避免 外界因素对植物产生不利影响, 确保其正常生长。

3.3 控制绿化材料质量 
园林绿化工程质量事故多数与绿化材料质量有着关 系,而且事故出现后往往难以弥补。因此实际中应该建立健 全材料监督体系,根本上避免不合格材料流人场地。配备专 业的材料管理与检测技术人员，在施工合同中规定材料的 质量要求, 详细说明监理方在材料监理中承担的责任与义 务。

\section{4 遵循植物生长规律}

确保园林绿化施工质量的主要措施就是保证苗木的成 活率, 这意味着施工人员需要掌握植物生长规律, 选择合适 时机进行栽培。目前反季节苗木栽种技术在绿化工程中得 到广泛应用,所谓的反季节种植技术,其本质就是在不适合 植株种植的季节进行种植。城市建设速度的加快对园林建 设提出更高更具体的要求, 如此背景下反季节种植技术也 需要产生相应的变化。实际中为满足园林绿化的需求, 很多 园林工程施工过程中就需要打破季节的限制, 进行反季节 种植。反季节园林建设时间一般情况下在 12 月到次年 1 月、6-9 月, 反季节种植过程中会受到各种因素的影响,包括 环境、气候及温度等,因此栽种后的植株往往存在根系脆弱 或休眠状态,造成存活率偏低的现实问题;对于名贵苗木的 移植,需要结合场地周边情况与气候, 营造出小范围合适苗 木生长的气候,提高苗木成活率。除此之外,一直完成后保证 水分的补充,做好灌溉时间与间隔的安排。

\section{4 重视园林绿化工程的后期养护管理}

园林绿化的后期养护管理具有十分重要的意义。它是 园林绿化工程质量的有效保障。因此,园林主管部门应尽快 出台统一的园林养护管理的相关要求与标准, 进一步使养 护工作更为规范化、合理化。同时,园林绿化施工单位,应切 实按照相关的后期养护管理标准, 形成一套行之有效的园 林绿化养护管理制度。

4.1 适当补充土壤养分

根据栽植植物的生长需要, 及时补充其所需的营养元 素。针对部分带有观赏性的植物,更应加强施肥管理。种植 之初, 不适合施重肥, 在苗木种植 2 月后进人梅雨季节, 对苗 木采取了施薄费的方法,促进其生长。等根系发育完全, 可以 正常施肥,促进生长。

4.2 排水防旱

当然,只保证土壤中有足够的养分还远远不够, 还要抓 好排水防早工作。对于行道树积水的现状,进行树穴开挖排 水,挖沟增设排水沟等措施。尤其是当暴雨过后,一定要检查
植物根部, 检查是否存在严重的积水或有所损坏等问题,及 时做好排水工作,从而防止因积水导致死亡。

对于新植树苗必须及时浇透定根水。同时,结合不同植 物所实际的需水量、种植时间以及当地的气候条件、土壤的 保水能力,在当年内采取适度的灌溉。应根据当地气候、土 质情况及栽植的树木大小、品种习性来确定实际的灌溉用 水量及灌溉次数。

4.3 重视对植物的整形

为了增添园林景观的美观性和可观赏性, 可对植物进 行合理的修剪整形。养护修剪一般分为日常修剪与冬季修 剪。日常修剪针对常绿乔木、常绿大灌木及各类小灌木, 冬 季修剪适用于落叶乔木,大型落叶花灌木。日常修剪避开夏 季,一般在春秋两季。特别针对球形及整形的苗木,需要缩短 修剪时间,以保证其整齐的美观度。

4.4 做好防寒、防虫工作

部分植物在冬季不宜过冬,采取绕草绳或包草包,保护 树干确保顺利过冬。针对植物的病虫害防治工作, 要遵循 “预防为主,防治结合”的治理原则。针对行道树香泡钻心虫 过多,采用人工捕虫和施药相结合的方法治虫, 有效控制虫 害。在病虫害防治过程中尽量减少农药的使用,多采用生态 型、环保型的方法进行治理,进而维护城市的生态环境。

\section{5 结束语}

园林绿化工程的施工及养护管理是一门实践性很强的 学科, 种植属于短期施工工程,养护管理属长期、周期性工 程。在实际工作中既要掌握园林工程原理,又要具备指导现 场施工及养护等方面的技能, 只有这样才能在保证工程质 量的前提下,较好地把园林绿化工程的科学性、技术性、艺 术性等有机地结合起来, 建造出既经济、又实用、且美观的 园林作品。

\section{参考文献:}

[1]周敏,马红英.浅谈园林施工管理与技术难点的几个 问题[J].四川建材,2015,(03):137.

[2]陈辉.园林绿化工程质量管理与控制分析[J].现代 园艺,2016,(18):185.

[3] 叶秀娟.如何对园林绿化树木进行修剪养护[J].黑 龙江科技信息,2017,34(08):124.

[4]赵大军.谈城市园林绿化树木养护管理[J]. 黑龙江 生态工程职业学院学报,2016,(09):28-29. 